\title{
Influence of Octacalcium Phosphate addition on physical-mechanical properties of Glass Ionomer Cement
}

Gabriela de Souza Balbinot ${ }^{a}$, Isadora Martini Garcia ${ }^{a}$, Fabricio Mezzomo Collares ${ }^{a}$, Susana Maria Werner Samuel ${ }^{a}$ Vicente Castelo Branco Leitune $^{a}$

\begin{abstract}
OBJECTIVE: The aim of this study was to evaluate the influence of octacalcium phosphate (OCP) addition to conventional glass ionomer cement (GIC).

METHODOLOGY: A commercial glass ionomer cement (Vidrion R - S.S. White Artigos Dentários Ltda - Rio de Janeiro, Brazil) was used in this study. OCP was added to powder in 1.5 and 3 wt\%. GIC without OCP addition was used as control. Specimens were produced to evaluate radiopacity, setting time and diametral tensile strength of cements. Radiopacity was assessed by phosphor plate system with alluminium step-wedge for comparison. For setting time determination, Gilmore needle $(100 \mathrm{~g})$ was used to determine final setting reaction. Diametral tensile strength was measured in a universal testing machine. Data were analyzed by one-way ANOVA at a significance level of 95\%. RESULTS: Results showed no statistically significant difference in tested properties with octacalcium phosphate addition in any concentration.

CONCLUSION: OCP addition to GIC did not influence materials properties.
\end{abstract}

Keywords: radiopacity; setting time; diametral tensile strength.

\section{Influência da adição de fosfato octacálcico nas propriedades físicas e mecânicas de um cimento de ionômero de vidro}

\section{RESUMO}

OBJETIVO: O objetivo deste estudo foi avaliar a influencia da adição de Fosfato Octacálcico (OCP) a um cimento de ionômero de vidro comercial (CIV)

METODOLOGIA: Um CIV comercial (Vidrion R - S.S. White Artigos Dentários Ltda - Rio de Janeiro, Brasil) foi utilizado no presente estudo. O OCP foi adicionado ao pó nas concentrações de $1.5 \%$ e $3 \%$ em peso. Para o grupo controle foi utilizado CIV sem adição de OCP. Os cimentos foram testados quanto a sua radiopacidade, tempo de presa e resistência à tração diametral. A radiopacidade foi avaliada por um sistema de placas de fósforo com escala de alumínio para comparação. Para avaliação do tempo de presa foram utilizadas agulhas de Gilmore $(100 \mathrm{~g})$ para determinar o período final da reação de presa. A resistência à tração diametral foi medida em uma máquina de ensaio universal. Os dados foram avaliados por meio de ANOVA de uma via com nível de significância de 95\%.

RESULTADOS: Não foi observada diferença estatística nas propriedades testadas nos grupos com adição de OCP em comparação com o grupo controle.

CONCLUSÃO: A adição de OCP não alterou as propriedades testadas do material testado.

Palavras-chave: ionômero de vidro; fosfatos de cálcio; teste de materiais. a Dental Materials Laboratory, School of Dentistry, Universidade Federal do Rio Grande do Sul, Porto Alegre, RS, Brazil
Correspondence:
Vicente Castelo Branco Leitune vicente.leitune@ufrgs.b

Received: July 25, 2017 Accepted: November 11, 2017

Conflict of Interests: The authors state that there are no financial and personal conflicts of interest that could have inappropriately influenced their work.

Copyright: @ 2017 Balbinot et al. licensee EDIPUCRS.

This work is licensed under a Creative Commons Attribution 4.0 International License. 


\section{INTRODUCTION}

Selective removal of carious lesions is a current strategy for minimal intervention in deep dentin [1]. It aims to conserve dental structure and reduce pulp exposure maintaining affected dentin on the floor of carious lesions. It is expected that physiological reaction in the pulp-dentin complex promote reactional dentin formation and pult tissue protection $[1,2]$. Success of this technique requires sealing of cavities to prevent bacterial infiltration and caries progression. Also, it is desirable that dentin remineralization occurs on the floor of the cavity[1].

Sealing of these cavities requires liners and restorative materials. Glass Ionomer Cements (GIC) can be applied in this case as liner for indirect pulp protection and as restorative material for sealing [2]. GIC's are water-based cements dispensed as a fluoro-aluminosilicate glass and a polyalkenoic acid, which reacts through acidic attack to the glass particles leading to ion release from the glass matrix. This is essential for GIC's application as calcium ions are responsible for bonding between cement and surrounding tissues which is key for good sealing of deep carious dentin cavities $[2,3]$.

For remineralization process, calcium and phosphate ions are required from external sources [4]. Thus a calcium phosphate agent could be added to GIC's to provide the amount of ions for remineralization of tooth. Octacalcium Phosphate (OCP) acts as source of calcium and phosphate due to its high solubility [5] and ability to promote hydroxyapatite nucleation and growth [6]. OCP has been suggested to induce osteoblast differentiation [7] and enhance osteoclast acitivity [8] promoting bone deposition in an in-vivo study [9] Some studies also showed OCP influence in odontoblast activity [10] and enhanced reactional dentin deposition $[10,11]$.

Due to desirable biological properties, it is important to understand how OCP behavior can interfere in GIC's setting reaction, radiopacity and mechanical properties. Hence, the aim of the present study is to evaluate the influence of OCP addition to a commercial GIC.

\section{MATERIAL AND METHODS}

\section{Study design}

Commercial GIC (Vidrion R - S.S. White Artigos Dentários Ltda - Rio de Janeiro, Brazil) was used in this study and manipulated according to manufacturer's instructions. All procedures were performed by the same operator. Briefly, 1:1 powder and liquid proportion was dispensed in a glass plate and mixed during one minute for incorporation of powder into the liquid. One measurement of powder was weighted and considered as standard for OCP addition in weight $\%$. One drop of liquid was also measures to maintain powder:liquid proportion. Experimental groups were produced by addition of $1.5 \mathrm{wt} \%$ and $3 \mathrm{wt} \%$ OCP to the powder. A control group without OCP addition was prepared. Cements were prepared and placed in mold for specimen preparation and allowed five minutes for setting reaction to complete. All specimens were left in $100 \%$ humidity environment at $37^{\circ} \mathrm{C}$ during $24 \mathrm{~h}$ before testing.

\section{Radiopacity}

Radiographic images were obtained using a phosphor plate digital system (VistaScan; Durr Dental GmbH \& Co. $\mathrm{KG}$, Bietigheim-Bissingen, Germany) at $70 \mathrm{kV}$ and $8 \mathrm{~mA}$, with $0.2 \mathrm{~s}$ of exposure time and a focus-film distance of $400 \mathrm{~mm}$. Five specimens were used for each group measuring $10.0 \mathrm{~mm}( \pm 0.5 \mathrm{~mm})$ in diameter and $1.0 \mathrm{~mm}( \pm 0.2 \mathrm{~mm})$ thickness. An aluminum step-wedge was simultaneously exposed for comparison. Images were analyzed using ImageJ $1.48 \mathrm{~d}$ software (Wayne Rasband, National Institutes of Health, USA). The means and standard deviations of the grey levels in pixel density of the aluminum step-wedge and the specimens were obtained in a standardized area. Mean values for the measurements were considered for radiopacity analysis.

\section{Setting time}

Powder and liquid were mixed as manufacturer's instruction during one minute working time. After preparation, cements were placed in a matrix with $10 \mathrm{~mm}$ diameter and $1 \mathrm{~mm}$ height. A Gilmore needle with $100 \mathrm{~g}$ and $2 \mathrm{~mm}$ flat end was placed vertically on the horizontal surface of the material for $5 \mathrm{~s}$, and this surface was visually inspected to verify indentations. This measurement was repeated every $15 \mathrm{~min}$, until no indentations was noticeable. The time period between cement's preparation and cement's setting was recorded. This procedure was performed three times and the setting time results were the mean of these three time measurements.

\section{Diametral Tensile Strength}

Five specimens were produced for each group in cylindrical Teflon molds measuring $(6.0 \pm 0.1) \mathrm{mm}$ high and $(4.0 \pm 0.1)$ diameter. After preparation, cements were injected into the mold until setting time. Right angles and flat ends were grid with 400 -grit silicon carbide papers. Diameters were measured at right angles and specimens were placed in a universal testing machine (EZ-SX Shimadzu, Japan) where force was applied along the diametral axis of the specimen with a cross-head speed of $(0.75 \pm 0.30) \mathrm{mm} / \mathrm{min}$. The maximum force applied for specimen fracture was used to diametral tensile strength, in MPa.

\section{Statistical analysis}

Data were subjected to Kolmogorov-Smirnov normality test and one way ANOVA at $95 \%$ level of significance $(\mathrm{p}>0,05)$.

\section{RESULTS}

Results of radiopacity, setting time and diametral tensile strength were shown in Table 1. An increase on cement radiopacity and setting time was observed for 3\% OCP 
addition, however no statistically significant difference was found for cement radiopacity and setting time. The highest value for diametral tensile strength was found in $1.5 \%$ OCP addition (10.12 MPa) with no statistically significant difference between experimental groups and control group.

Table1. Mean and standard deviation values of radiopacity (mmAl), setting time (s) and diametral tensile strength ( $\mathrm{MPa}$ ) for experimental and control groups.

\begin{tabular}{cccc}
\hline & $\begin{array}{c}\text { Radiopacity } \\
(\text { mmAl) }\end{array}$ & $\begin{array}{c}\text { Setting Time } \\
(\mathbf{s})\end{array}$ & $\begin{array}{c}\text { Diametral Tensile } \\
\text { Strength } \\
(\mathrm{MPa})\end{array}$ \\
Control & $0.476 \pm 0.254^{\mathrm{A}}$ & $405.333 \pm 30.089^{\mathrm{A}}$ & $7.01 \pm 4.10^{\mathrm{A}}$ \\
$1.5 \%$ & $0.439 \pm 0.209^{\mathrm{A}}$ & $416.000 \pm 61.733^{\mathrm{A}}$ & $10.12 \pm 3.53^{\mathrm{A}}$ \\
$3.0 \%$ & $0.553 \pm 0.330^{\mathrm{A}}$ & $486.667 \pm 66.890^{\mathrm{A}}$ & $6.62 \pm 1.25^{\mathrm{A}}$ \\
\hline
\end{tabular}

\section{DISCUSSION}

In the present study, the addition of OCP in commercial GIC's did not change radiopacity, setting time and diametral tensile strenght (Table 1). The addition of bioactive particles into GIC $[12,13]$ has been shown as a strategy to remineralize dental tissues and $\mathrm{OCP}$, as a highly soluble calcium phosphate could act as source for $\mathrm{Ca}^{2+}$ and $\mathrm{PO}_{3-}^{4}$ for apatite deposition [7] in deep carious lesions when clinical procedures such as selective caries removal is applied $[2,14]$. Although fluoride release from GIC's reaction is related to tissue remineralization, it did not result in interfibrillar or intrafibrillar remineralization of demineralized collagen in dentin matrix [15] and thus, no remineralizing effect can be observed in available glass ionomer cements. Solubility of OCP is expected to promote increased calcium and phosphate leaching when OCP is added to GIC's. The amount of released ions in setting reaction of these cements is not clear, however demineralized dentin showed reduced amount of calcium and phosphate, requiring great amount of external ions for remineralization [4]. In this study, $1.5 \mathrm{wt} \%$ and $3 \mathrm{wt} \%$ of OCP was added and could increase the amount of ions available for remineralization with no effect on conventional GIC's physical and mechanical properties.

It's known that mechanical properties of GIC's are inferior to other restorative materials like composite resins $[16,17]$ but available commercial cements presents suitable properties for several applications. The addition of bioactive particles has been shown to reduce GIC's mechanical properties, however both concentrations of OCP added to GIC did not interfere in diametral tensile strength of experimental groups compared to control. Also, similar results were found in other studies $[13,18]$. Final strength of GIC's are related to the amount of $\mathrm{Al}^{3+}$ available during setting reaction which is responsible for cross-linking with polyacrylic acid giving final strength to the material. As $1.5 \mathrm{wt} \%$ and $3 \mathrm{wt} \%$ were added to glass matrix there were probably no great change in $\mathrm{Al}^{3+}$ availability for reaction.

The amount of available ions from the powder to react in acidic conditions can influence setting time as well.
Decreased setting time is expected when bioactive fillers are added to GIC's powder due to reduction on interaction between fluoraluminesilicate glass and polyacrilic acid. Although increased setting time was observed (Table 1), no statistical difference was found between $1,5 \mathrm{wt} \%$ and $3 \mathrm{wt} \%$ addition of OCP to glass powder. Also, results are in agreement with other studies $[3,13]$ and in accordance with ISO 9917-1 requirements [19]. Thus, these changes in setting time may not influence cements handling or increase chair time which may be influenced by longer setting reactions.

Radiopacity are an important feature for dental and especially restorative materials [20]. The detection of secondary caries and gaps in tooth-material interface through radiographic exams are important for clinical practice and demand adequate radiopacity for restorative materials to be differentiated from surrounded mineralized tissues [21]. No statistical difference was observed for experimental cements compared to control group in this study which is expected as both GIC's and OCP did not present components with high atomic number to increased radiopacity values. Several materials were studied as radiopaque fillers for GIC's such as Niobium [22] and Strontium [23] and further studies could be conducted with the addition of both bioactive and radipacificant components to glasses matrix.

\section{CONCLUSION}

Addition of OCP to GIC's did not influence material's diametral tensile strenght, radiopacity or setting reaction showing possible application of this bioactive particle to enhance GIC's ability to promote tooth remineralization.

\section{REFERENCES}

1. Alves LS, Fontanella V, Damo AC, Ferreira de Oliveira E, Maltz M Qualitative and quantitative radiographic assessment of sealed carious dentin: a 10-year prospective study. Oral Surg Oral Med Oral Pathol Oral Radiol Endod. 2010 Jan;109(1):135-41. https://doi.org/10.1016/j. tripleo.2009.08.021

2. Corralo DJ, Maltz M. Clinical and ultrastructural effects of different liners/ restorative materials on deep carious dentin: a randomized clinical trial. Caries Res. 2013;47(3):243-50. https://doi.org/10.1159/000345648

3. Kiri L, Boyd D. Predicting composition-property relationships for glass ionomer cements: A multifactor central composite approach to material optimization. J Mech Behav Biomed Mater. 2015 Jun;46:285-91. https:// doi.org/10.1016/j.jmbbm.2015.02.007

4. Yang B, Flaim G, Dickens SH. Remineralization of human natural caries and artificial caries-like lesions with an experimental whisker-reinforced ART-composite. Acta Biomater. 2011 May;7(5):2303-9. https://doi. org/10.1016/j.actbio.2011.01.002

5. Dorozhkin SV. Calcium orthophosphates in dentistry. J Mater Sci Mater Med. 2013 Jun;24(6):1335-63. https://doi.org/10.1007/s10856-013-4898-1

6. Suzuki O. Octacalcium phosphate: osteoconductivity and crystal chemistry Acta Biomater. 2010 Sept;6(9):3379-87. https://doi.org/10.1016/j. actbio.2010.04.002

7. Suzuki O, Kamakura S, Katagiri T. Surface chemistry and biological responses to synthetic octacalcium phosphate. J Biomed Mater Res B Appl Biomater. 2006 Apr;77(1):201-12. https://doi.org/10.1002/ jbm.b.30407

8. Takami M, Mochizuki A, Yamada A, Tachi K, Zhao B, Miyamoto Y, et al Osteoclast differentiation induced by synthetic octacalcium phosphate through receptor activator of NF-kappaB ligand expression in osteoblasts. Tissue Eng Part A. 2009 Dec;15(12):3991-4000. https://doi.org/10.1089/ ten.tea.2009.0065 
9. Suzuki O, Kamakura S, Katagiri T, Nakamura M, Zhao B, Honda Y, et al. Bone formation enhanced by implanted octacalcium phosphate involving conversion into Ca-deficient hydroxyapatite. Biomaterials. 2006 May;27(13):2671-81. https://doi.org/10.1016/j.biomaterials.2005.12.004

10. Wang X, Suzawa T, Miyauchi T, Zhao B, Yasuhara R, Anada T, et al. Synthetic octacalcium phosphate-enhanced reparative dentine formation via induction of odontoblast differentiation. J Tissue Eng Regen Med. 2015 Nov;9(11):1310-20. https://doi.org/10.1002/term.1669

11. Sena M, Yamashita Y, Nakano Y, Ohgaki M, Nakamura S, Yamashita K, et al. Octacalcium phosphate-based cement as a pulp-capping agent in rats. Oral Surg Oral Med Oral Pathol Oral Radiol Endod. 2004 Jun;97(6):749-55. https://doi.org/10.1016/j.tripleo.2003.10.029

12. De Caluwé T, Vercruysse CWJ, Ladik I, Convents R, Declercq H, Martens $\mathrm{LC}$, et al. Addition of bioactive glass to glass ionomer cements: Effect on the physico-chemical properties and biocompatibility. Dent Mater. 2017 Apr 1;33(4):e186-203. https://doi.org/10.1016/j.dental.2017.01.007

13. Kim D-A, Lee J-H, Jun S-K, Kim H-W, Eltohamy M, Lee H-H. Sol-gelderived bioactive glass nanoparticle-incorporated glass ionomer cement with or without chitosan for enhanced mechanical and biomineralization properties. Dent Mater Off Publ Acad Dent Mater. 2017 Jul;33(7):805-17. https://doi.org/10.1016/j.dental.2017.04.017

14. Ngo HC, Mount G, Mc Intyre J, Tuisuva J, Von Doussa RJ. Chemica exchange between glass-ionomer restorations and residual carious dentine in permanent molars: an in vivo study. J Dent. 2006 Sep;34(8): 608-13. https://doi.org/10.1016/j.jdent.2005.12.012

15. Kim YK, Yiu CKY, Kim JR, Gu L, Kim SK, Weller RN, et al. Failure of a Glass Ionomer to Remineralize Apatite-depleted Dentin. J Dent Res. 2010 Mar;89(3):230-5. https://doi.org/10.1177/0022034509357172

16. Sidhu SK. Clinical evaluations of resin-modified glass-ionomer restorations. Dent Mater. 2010 Jan 1;26(1):7-12. https://doi.org/10.1016/j. dental.2009.08.015
17. Peumans M, De Munck J, Mine A, Van Meerbeek B. Clinical effectiveness of contemporary adhesives for the restoration of non-carious cervical lesions. A systematic review. Dent Mater Off Publ Acad Dent Mater. 2014 Oct;30(10):1089-103. https://doi.org/10.1016/j.dental.2014.07.007

18. Silva RM, Pereira FV, Mota FAP, Watanabe E, Soares SMCS, Santos MH. Dental glass ionomer cement reinforced by cellulose microfibers and cellulose nanocrystals. Mater Sci Eng C. 2016 Jan 1:58:389-95. https:// doi.org/10.1016/j.msec.2015.08.041

19. ISO 9917-1:2007(en), Dentistry - Water-based cements - Part 1: Powder/ liquid acid-base cements [Internet]. [cited 2016 Jun 12]. Available from: https://www.iso.org/obp/ui/\#iso:std:iso:9917:-1:ed-2:v1:en

20. Collares FM, Ogliari FA, Lima GS, Fontanella VRC, Piva E, Samuel SMW Ytterbium trifluoride as a radiopaque agent for dental cements. Int Endod J. 2010 Sep;43(9):792-7. https://doi.org/10.1111/j.1365-2591.2010.01746.x

21. Hitij T, Fidler A. Radiopacity of dental restorative materials. Clin Oral Investig. 2013 May;17(4):1167-77. https://doi.org/10.1007/s00784-0120797-y

22. Garcia IM, Leitune VCB, Balbinot GDS, Samuel SMW, Collares FM. Influence of niobium pentoxide addition on the properties of glass ionomer cements. Acta Biomater Odontol Scand. 2016 Oct 5;2(1):138-43. https:// doi.org/10.1080/23337931.2016.1239182

23. Shahid S, Hassan U, Billington RW, Hill RG, Anderson P. Glass ionomer cements: Effect of strontium substitution on esthetics, radiopacity and fluoride release. Dent Mater. 2014 Mar;30(3):308-13. https://doi. org/10.1016/j.dental.2013.12.003 